\title{
Penelusuran Informasi pada Pemustaka Universitas Negeri Padang
}

\author{
Malta Nelisa dan Ardoni \\ Universitas Negeri Padang \\ Email: malta@fbs.unp.ac.id
}

\begin{abstract}
Information search is important in supporting the activity of "Tri Dharma Perguruan Tinggi". Student information search results are often found to be very similar to statements in the reference used. Skills in the use of information reflect the understanding of college librarians against information literacy. The research method used in compiling this article is by qualitative research. In this research used information tracing model with stages namely: starting, chaining, browsing, differentiating, monitoring, extracting, verifying, and ending. The study was conducted on 143 users from State University of Padang (UNP) and University of Andalas (Unand). The results showed that the lecturer is an important source of information for the user to know the initial reference that will be used in the completion of academic tasks. In addition, college librarians have a high dependence on internet resources. In terms of the formulation of information retrieval results, some readers use the full statement in reference. In other words, the user does not formulate the search results according to his or her understanding. However, some others do a search for information as in the search model referenced in this study.
\end{abstract}

Keywords: information tracking; information literacy; college librarian 


\begin{abstract}
Abstrak
Penelusuran informasi merupakan hal penting dalam mendukung aktivitas Tri Dharma Perguruan Tinggi. Hasil penelusuran informasi yang dilakukan mahasiswa sering ditemukan sangat mirip dengan pernyataan pada referensi yang digunakan. Keterampilan dalam pemanfaatan informasi mencerminkan pemahaman pemustaka perguruan tinggi terhadap literasi informasi. Metode penelitian yang digunakan dalam menyusun artikel ini adalah dengan qualitative research. Dalam penelitian ini digunakan model penelusuran informasi dengan tahapan yaitu: starting, chaining, browsing, differentiating, monitoring, extracting, verifying, dan ending. Penelitian dilakukan pada 143 pemustaka dari Universitas Negeri Padang (UNP) dan Universitas Andalas (Unand). Hasil penelitian menunjukkan bahwa dosen merupakan sumber informasi penting bagi pemustaka untuk mengetahui referensi awal yang akan digunakan dalam penyelesaian tugas akademik. Selain itu, pemustaka perguruan tinggi punya ketergantungan yang tinggi pada sumber-sumber internet. Dalam hal perumusan hasil penelusuran informasi, sebagian pemustaka menggunakan secara penuh pernyataan dalam referensi. Dengan kata lain, pemustaka tidak merumuskan hasil penelusuran sesuai dengan pemahamannya. Namun, sebagian lainnya melakukan penelusuran informasi seperti pada model penelusuran yang dirujuk dalam penelitian ini.
\end{abstract}

Kata kunci: penelusuran informasi; literasi informasi; pemustaka perguruan tinggi

\title{
Pendahuluan
}

Perguruan tinggi adalah tempat terlaksananya kegiatan komunikasi ilmiah. Dalam konsep komunikasi ilmiah, perkembangan ilmu pengetahuan akan lebih cepat jika terdapat transfer pengetahuan melalui publikasi ilmiah. Untuk mendukung hal tersebut, dosen dan mahasiswa membutuhkan sumber informasi terbaru sehingga bisa mengembangkan bidang ilmu yang menjadi objek studinya. Selain penggunaan sumber informasi perpustakaan, kecepatan dan ketepatan pencarian informasi dianggap penting oleh pemustaka dalam mengakses informasi. Pustakawan perlu mengetahui kebutuhan informasi pemustaka untuk dapat menyediakan sumber-sumber dan sarana penelusuran informasi yang tepat guna dan bernilai guna.

Sumber-sumber informasi (koleksi) perpustakaan dimanfaatkan oleh pemustaka perguruan tinggi untuk mendukung aktivitas Tri Dharma Per- 
guruan Tinggi yang mencakup pendidikan dan pengajaran, penelitian, dan pengabdian kepada masyarakat. Ketersediaan koleksi perpustakaan sesuai dengan kebutuhan pengguna informasi dan ketersediaan sarana penelusuran informasi yang friendly, dapat meningkatkan kualitas perpustakaan di mata pemustaka. Hal ini merupakan salah satu faktor penting yang menjadi pertimbangan bagi pemustaka dalam menjadikan perpustakaan sebagai tempat utama dalam pencarian informasi. Apalagi di era teknologi informasi dan komunikasi saat ini, informasi dapat diakses dimanapun dan kapanpun dibutuhkan.

Visi dan misi perpustakaan perguruan tinggi harus sejalan dengan visi dan misi perguruan tinggi yang mendukung pelaksanaan tri dharma. UndangUndang No. 43 Tahun 2007 tentang Perpustakaan dalam pasal 12 ayat (1) menyatakan: "Koleksi perpustakaan dipilih, diproses, disimpan, dilayani, dan dikembangkan sesuai dengan kepentingan pengguna dengan memperhatikan perkembangan teknologi informasi dan komunikasi”. Selanjutnya, pada pasal 24 ayat (2) disebutkan: "Perpustakaan perguruan tinggi memiliki koleksi, baik jumlah judul maupun jumlah eksemplar yang cukup untuk mendukung pelaksanaan pendidikan, penelitian, dan pengabdian kepada masyarakat". Kedua pernyataan tersebut merupakan acuan bagi perpustakaan perguruan tinggi untuk melaksanakan kewajibannya mengembangkan perpustakaan dalam rangka pemenuhan kebutuhan informasi pemustaka. Selain koleksi, sarana penelusuran menjadi hal penting yang harus disediakan untuk kelancaran proses penelusuran informasi.

Perpustakaan perguruan tinggi yang menjadi sampel dalam penelitian ini adalah dua perguruan tinggi negeri yang terdapat di Kota Padang, Provinsi Sumatera Barat. Perguruan tinggi tersebut yaitu Universitas Negeri Padang (UNP) dan Universitas Andalas (Unand). Ditinjau dari kluster ilmu pengetahuan, UNP memayungi program studi yang sebagian besar mencakup ilmu kependidikan, sedangkan Unand memayungi program studi dari bidang sains murni dan terapan. Pada dasarnya, kedua perguruan tinggi memiliki jenis layanan perpustakaan yang sama. Hanya terdapat sedikit perbedaan layanan, yaitu dengan adanya layanan sumber informasi khusus seperti: Minangkabau Corner, American Corner, French Corner, dan Popular Corner. 
Semakin banyak layanan informasi yang diberikan oleh perpustakaan akan menambah variasi strategi pencarian informasi oleh pemustaka. Penelitian ini memberikan penjelasan tentang strategi penelusuran informasi pemustaka perguruan tinggi, sehingga diharapkan nantinya perpustakaan dapat mengembangkan sumber informasi yang sesuai untuk kebutuhan informasi pemustaka. Selain itu, perpustakaan dapat mempertimbangkan untuk menambahkan layanan informasi lainnya untuk pengembangan perpustakaan dan untuk meningkatkan kualitas perpustakaan perguruan tinggi.

\section{Penelusuran informasi sangat berkaitan dengan konsep-konsep literasi informasi}

Reitz (2004: 356) menyatakan bahwa literasi informasi adalah kemampuan untuk menemukan informasi yang dibutuhkan dan memahami bagaimana menggunakan perpustakaan, mengetahui sumber informasi yang ada, dan merupakan pengetahuan yang biasanya digunakan secara teknis dalam pencarian informasi. Selain itu, Septiyantono (2016: 1.12) menyatakan bahwa: (1) literasi informasi adalah kemampuan seseorang untuk menemukan, menganalisis, mengevaluasi, dan mengkomunikasikan informasi; (2) literasi informasi didukung oleh peran perpustakaan dalam mengenalkan istilah literasi informasi, membantu memperoleh kemampuan literasi informasi, dan menyediakan akses informasi yang mudah; (3) penguasaan terhadap teknologi informasi memberikan kemudahan bagi seseorang untuk memiliki kemampuan literasi informasi. Berdasarkan pengertian tersebut, dapat disimpulkan bahwa literasi informasi merupakan berbagai kemampuan yang digunakan dalam penelusuran dan pemanfaatan informasi.

Secara khusus Association and College Research of Library (ACRL) (2000), merumuskan standar kompetensi literasi informasi untuk perguruan tinggi sebagai berikut. (1) Kemampuan untuk menentukan sifat dan cakupan informasi yang dibutuhkan dengan cakupan: menentukan kebutuhan informasi, mengidentifikasi berbagai jenis dan format sumber informasi potensial dengan mempertimbangkan biaya dan manfaat pengambilan 
informasi yang dibutuhkan, dan mengevaluasi kembali sifat dan lingkup informasi yang dibutuhkan. (2) Kemampuan untuk mengakses informasi yang dibutuhkan secara efektif dan efisien dengan cakupan: memilih metode pengambilan atau pengambilan informasi yang paling tepat untuk menemukan informasi yang dibutuhkan, membangun dan menerapkan strategi pencarian yang efektif, menemukan kembali informasi secara daring (online) atau metode penggunaan pribadi, perubahan strategi pencarian jika perlu, mencatat dan memproses informasi dan sumber daya. (3) Mengevaluasi informasi dan sumber daya secara kritis dengan cakupan: merangkum gagasan utama yang dikutip dari informasi yang dikumpulkan, mempublikasikan dan menggunakan kriteria awal untuk mengevaluasi informasi dan sumber daya, mengumpulkan gagasan utama untuk membangun konsep baru, membandingkan pengetahuan baru dengan pengetahuan sebelumnya untuk menentukan nilai tambah, kontradiksi, atau karakteristik informasi unik lainnya, menentukan apakah pengetahuan baru berdampak pada sistem nilai dan memiliki cara untuk menyatukan perbedaan, memvalidasi pemahaman dan interpretasi informasi melalui diskusi dengan individu laini. (4) Menggunakan informasi untuk mencapai tujuan yang spesifik dengan cakupan: menggunakan informasi untuk perencanaan dan pembuatan hasil atau kinerja yang luar biasa, dan secara efektif mengkomunikasikan hasilnya kepada orang lain. (5) Memahami aspek ekonomi, hukum dan sosial yang terkait dengan penggunaan informasi, yaitu: memahami isu seputar informasi dan teknologi informasi, mengikuti peraturan dan etika terkait penggunaan sumber informasi, dan menghormati penggunaan sumber informasi dalam mengkomunikasikan produk informasi.

Salah satu faktor sukses atau tidaknya kegiatan literasi informasi bergantung pada strategi dalam penelusuran informasi. Ellis, Cox, dan Hall dalam Septiyantono (2016: 7.26) mengemukakan model penelusuran informasi yang dijelaskan dalam bentuk fase pencarian informasi. Model ini mencakup delapan fase, yaitu starting, chaining, browsing, differentiating, monitoring, extracting, verifying, dan ending. (1) Starting adalah pengantar awal referensi untuk menemukan informasi yang akan diteliti lebih lanjut 
menggunakan sumber informasi sekunder seperti abstrak, indeks, katalog subjek, pratinjau atau sinopsis artikel, serta catatan buatan sendiri mengenai topik yang diminati. (2) Chaining, pada tahap ini aktivitas pengguna menghubungkan daftar literatur dengan referensi inti. Cara untuk melakukannya adalah dengan mencari atau melihat daftar pustaka yang terdapat dalam referensi inti atau mencari rujukan lain berdasarkan subjek atau nama penulis dari referensi inti yang digunakan. (3) Browsing, adalah kegiatan pencarian informasi yang dilakukan untuk mengidentifikasi sumber informasi potensial di bidang yang minati, seperti melalui abstrak penelitian, daftar jurnal, sumber informasi perpustakaan atau buku-buku di pameran atau seminar. (4) Differentiating, merupakan kegiatan untuk membedakan sumber informasi untuk memfilter informasi berdasarkan kualitas rujukan, misalnya melalui topik studi atau pendekatan yang digunakan. (5) Monitoring, merupakan kegiatan untuk memantau perkembangan yang terjadi di bidang minat melalui akses terhadap sumber informasi secara berkala. Sumber informasi yang digunakan meliputi artikel jurnal, komunikasi ilmiah dengan rekan kerja atau ahli, atau pemantauan materi yang diterbitkan dalam bentuk buku. (6) Extracting, tahap ini digunakan saat membuat kajian pustaka dengan memilih informasi melalui jurnal, katalog, bibliografi, abstrak, dan indeks. (7) Verifying, suatu kegiatan penilaian informasi, apakah sudah sesuai dan tepat dengan yang diinginkan. (8) Ending, adalah tahap akhir dari pencarian informasi yang bertepatan dengan akhir kegiatan penelitian atau terjawabnya permasalahan yang dibahas pengguna informasi.

\section{Metode Penelitian}

Penelitian ini dilakukan dengan metode kualitatif. Jenis sampel yang digunakan adalah incidental sampling. Dalam penelitian ini terdapat 143 sampel pemustaka yang memanfaatkan layanan Perpustakaan Universitas Negeri Padang (UNP) dan Perpustakaan Universitas Andalas (Unand). Pemustaka tersebut semuanya adalah mahasiswa dari kedua perguruan tinggi. Indikator penelitian dibuat dengan menggunakan model penelusuran informasi dari Ellis, Cox, and Hall dalam Sugiyantono (2016: 7.27) yang 
meliputi: starting, chaining, browsing, differentiating, monitoring, extracting, verifying, dan ending. Analisis data dilakukan dengan melakukan tinjauan terhadap hasil instrumen penelitian dan membandingkan dengan konsep yang digunakan dalam penelitian. Selanjutnya, dikembangkan strategi penyediaan dan pemanfaatan sarana penelusuran informasi bagi pustakawan dan pemustaka perguruan tinggi.

\section{Pembahasan}

Hasil penelitian ini dibahas dalam tiga bagian, yaitu: (1) penelusuran informasi pemustaka perguruan tinggi, (2) strategi penyediaan sarana penelusuran informasi perpustakaan, dan (3) strategi penelusuran informasi bagi pemustaka perguruan tinggi.

\section{Penelusuran Informasi pada Pemustaka Perguruan Tinggi}

Model penelusuran informasi yang digunakan dalam penelitian ini mengacu pada model yang dikemukakan oleh Ellis, Cox, dan Hall dalam Septiyantono (2016: 7.26), yaitu: starting, chaining, browsing, differentiating, monitoring, extracting, verifying, dan ending.

Pertama, tahap starting yang merupakan titik awal pencarian informasi. Pada tahap ini pemustaka mendapatkan informasi awal tentang topik yang akan dibahas atau diteliti. Tahap ini juga merupakan referensi awal bagi pemustaka yang didapat melalui orang-orang disekitarnya. Sebagian besar pemustaka mendapatkan informasi awal tentang rujukan atau sumber informasi yang akan digunakan untuk penyelesaian tugas kuliah atau penelitian yaitu dari teman sejawat atau dosen. Peran dosen sebagai fasilitator komunikasi ilmiah sangat penting untuk mengarahkan dan membimbing mahasiswa dalam mencari sumber informasi berkualitas. Dari data responden diketahui bahwa sebagian besar merupakan mahasiswa semester satu, sehingga dapat diasumsikan bahwa mereka ke perpustakaan untuk mencari informasi untuk menyelesaikan tugas perkuliahan. Responden yang berada di semester akhir, yaitu semester 7 dan semester 9 berjumlah sebagian kecil dari responden penelitian, sehingga dapat diasumsikan juga topik yang 
dicari juga terkait dengan kegiatan penelitian untuk menyelesaikan tugas akhir seperti skripsi.

Sumber referensi awal dalam penentuan topik untuk pembuatan tugas kuliah dan penelitian juga berasal dari membaca ulasan atau sinopsis artikel, dan informasi melalui kumpulan abstrak serta katalog perpustakaan. Kegiatan perpustakaan perguruan tinggi tidak hanya terfokus pada layanan peminjaman dan pengembalian koleksi (layanan sirkulasi). Sumber informasi sekunder seperti: koleksi abstrak, indeks, bibliografi, dan katalog perpustakaan perlu dimaksimalkan pendayagunaannya oleh pemustaka. Banyak pemustaka tidak mengetahui isi jurnal ilmiah karena pustakawan tidak menginformasikan artikel ilmiah perpustakaan ke dalam bentuk lain yang memudahkan pencarian informasi, yaitu sarana penelusuran informasi. Ketersediaan OPAC (Online Public Access Catalog) di banyak perguruan tinggi masih mendominasi untuk memudahkan penelusuran pada koleksi untuk layanan sirkulasi. Sementara itu, sumber informasi lain seperti publikasi berkala belum maksimal dikelola sehingga pemustaka belum bisa dengan mudah menemukan artikel yang terdapat di dalamnya. Padahal terbitan berkala, khususnya jurnal adalah sumber informasi penting di perguruan tinggi yang berperan dalam komunikasi ilmiah untuk percepatan perkembangan ilmu pengetahuan.

Berdasarkan hal tersebut, pembuatan kumpulan abstrak artikel atau sinopsis artikel sebaiknya dilakukan tidak hanya dalam bentuk tercetak saja. Produk informasi harus diintegrasikan dalam sistem informasi perpustakaan, sehingga selain mengetahui isi artikel dengan ringkas, pemustaka juga dapat menemukan informasi fisik melalui informasi terperinci mengenai keberadaan sumber informasi. Atau, sistem informasi perpustakaan juga bisa menyediakan artikel fulltext agar bisa diakses pemustaka dimanapun dan kapanpun. Tersedianya sumber informasi sekunder seperti ini akan memudahkan pengguna dalam mendapatkan ide atau topik yang diminati.

Kedua, tahap chaining yaitu kegiatan penelusuran informasi untuk menemukan sumber rujukan lanjutan menggunakan informasi yang terdapat dalam daftar referensi inti. Pada tahap ini pemustaka juga mencari referensi 
lain, namun tetap berdasarkan nama penulis dan subjek yang terdapat dalam referensi inti. Alternatif kedua pada tahap ini adalah penelusuran informasi melalui abstrak penelitian atau daftar isi jurnal. Penggunaan metode ini selanjutnya dapat memperluas cakupan informasi yang diinginkan pemustaka, karena melalui abstrak penelitian dan daftar isi jurnal terdapat kemungkinan untuk mencari informasi yang sesuai dengan topik yang diminati.

Hasil analisis terhadap pemustaka kedua perguruan tinggi untuk tahap ini adalah tidak banyak pemustaka yang menggunakan referensi lanjutan atau mencari informasi melalui abstrak penelitian maupun daftar isi jurnal. Hal ini diasumsikan karena kecenderungan pengguna untuk merujuk pada sumber informasi berupa buku teks dan kurangnya pengetahuan tentang penggunaan abstrak hasil penelitian serta daftar isi jurnal. Pemustaka dapat mencari lebih banyak informasi melalui bibliografi yang terdapat pada referensi inti. Pada tahap ini ada dua cara untuk melacak informasi, melalui daftar referensi utama perpustakaan dan melalui penggunaan penulis atau nama subjek dalam daftar referensi inti. Dengan cara yang kedua, pelacakan informasi dibantu dengan cara melacak informasi seperti alat bibliografi. Alat ini seringkali tersedia tidak diperbaharui di perpustakaan, sehingga sedikit pemustaka yang merujuk ke sumber-sumber ini. Di sisi lain, pemustaka terkadang tidak mengetahui fasilitas ini di perpustakaan dan tidak tahu bagaimana menggunakannya untuk membantu penelusuran informasi. Sumber informasi seperti ini jika selalu diperbarui oleh pustakawan dapat mempercepat pengembangan ilmu pengetahuan seperti konsep komunikasi ilmiah.

Ketiga, tahap browsing, yaitu penelusuran lanjutan dari Informasi tentang referensi yang telah diperoleh pada tahap sebelumnya. Sumber informasi yang paling banyak digunakan sebagai rujukan adalah sumber internet. Sumber ini dianggap memberikan jawaban paling cepat terhadap pertanyaan atau masalah dalam tugas akademik pemustaka karena dapat diakses kapanpun dan dimanapun selama pengguna memiliki perangkat teknologi informasi dan komunikasi, minimal handphone atau smartphone. 
Dalam penelitian ini, belum diketahui apakah sumber internet yang digunakan oleh pemustaka adalah sumber informasi dengan konten yang valid, jelas, dan akuntabel. Mengamati ketersediaan informasi di sumber internet saat ini, pemustaka harus pintar dalam memilih informasi apalagi untuk kepentingan penulisan karya ilmiah.

Sumber yang sering dirujuk selanjutnya adalah buku perpustakaan, terbitan berkala seperti surat kabar dan majalah, serta sumber referensi seperti kamus, direktori atau ensiklopedi. Terkadang pengguna juga mencari informasi melalui pameran buku. Berdasarkan hal tersebut dapat diketahui bahwa sebagian besar pemustaka menggunakan beragam sumber informasi dalam menyelesaikan tugas akademik. Namun, hanya sebagian kecil pemustaka yang memanfaatkan koleksi referensi perpustakaan untuk mendukung aktivitas akademis mereka.

Keempat, tahap differentiating, yaitu pemilihan sumber informasi berdasarkan kualitas rujukan. Kualitas yang dimaksud adalah dengan mengidentifikasi sumber informasi yang menekankan pada subyek yang dipilih untuk lebih lanjut mengambil informasi yang diinginkan. Pemustaka dapat memilih referensi yang relevan dari semua referensi yang telah dikumpulkan. Secara umum, pada tahap ini pemustaka membedakan sumber informasi berdasarkan ketersediaan subjek yang diinginkan, termasuk kedalaman materi mengenai topik yang diinginkan. Pertimbangan lain adalah kredibilitas, yaitu sejauh mana sumber informasi dapat dipercaya dan update informasinya. Namun, tidak banyak pemustaka yang melakukan tahap ini. Sehingga, diasumsikan pemustaka langsung menggunakan sumber informasi yang didapat tanpa mengumpulkan semua sumber yang relevan. Pada tahap ini diperlukan keterampilan dalam mengidentifikasi sumber informasi baik dari topik studi maupun kualitas sumbernya.

Kelima, tahap monitoring yaitu pemantauan kegiatan melalui pengamatan terhadap perkembangan yang terjadi pada topik yang diminati. Sebagian besar pemustaka melakukan ini dengan berkomunikasi dengan teman sejawat dan dosen. Selain itu, pemustaka juga mengakses katalog perpustakaan. Hubungan formal menjadi pilihan utama karena dapat 
dijadikan sarana pertukaran informasi yang lebih cepat. Sumber informasi lain yang digunakan oleh pemustaka adalah jurnal dan katalog. Dalam komunikasi ilmiah, akses terhadap publikasi berkala disarankan untuk memantau informasi dari sumber lain. Hal ini terkait dengan karakter sumber ini yaitu dapat menyebarkan informasi terbaru lebih cepat daripada publikasi buku. Selain itu, artikel dalam jurnal dianggap lebih bertanggung jawab dalam hal konten karena merupakan bentuk penelitian ringkas yang telah dilaksanakan atau studi mendalam dengan menggunakan sumber informasi relevan tentang sebuah topik.

Keenam, tahap extracting. Tahap ini membutuhkan keahlian pemustaka dalam mengekstrak informasi dari berbagai sumber. Sebagian pemustaka menyarikan informasi dari semua sumber informasi yang dianggap relevan dengan topik atau masalah yang akan dibahas. Namun, sebagian lainnya hanya sesekali melakukan tahap ini. Berdasarkan hal ini diasumsikan bahwa sebagian pemustaka lainnya menggunakan langsung informasi yang didapat dari sumber informasi dalam penulisan tugas akademik tanpa menyarikan dari beberapa sumber. Pemustaka jarang menulis ulang informasi yang telah didapat dengan bahasa mereka sendiri.

Tahap ini sering diabaikan oleh pemustaka, padahal tahap ini merupakan tahap penting dimana pemustaka menuliskan kembali semua informasi yang telah diperoleh untuk dikembangkan sesuai pemahaman dan disinkronisasikan dengan topik permasalahan yang harus dipecahkan. Mengestrak informasi dari berbagai sumber membutuhkan kemampuan membaca cepat dan membaca pemahaman. Diantara banyak sumber informasi yang telah dikumpulkan, mungkin sebagian berisi informasi dengan maksud yang sama. Selain itu, pemahaman bacaan bisa lebih efektif dalam mencari informasi sekaligus memetakan jawaban yang terkandung dalam sumber-sumber ini, sehingga penyelesaian tugas akademik berupa tugas kuliah dan tugas akhir seperti skripsi dapat dilakukan secara efisien. Penerapan tahap ini secara serius dapat melatih dan membiasakan pemustaka untuk belajar mandiri dan menghasilkan karya ilmiah asli, sehingga mengurangi praktik plagiarisme. 
Ketujuh, tahap verifying. Pada tahap ini pencari informasi melakukan pengecekan atau pengkajian ulang atas informasi yang telah diperoleh. Pemustaka memastikan informasi yang mereka dapatkan sesuai dengan keinginan mereka. Apabila tahap ini tidak dilakukan, akan berakibat pada hasil tugas akademik yang kurang memuaskan dalam hal kualitas. Selain itu, bisa diasumsikan pemustaka tidak memahami tugas yang telah dibuat. Sebagian kecil pemustaka tidak mengecek ulang informasi yang didapat apakah relevan dengan apa yang dibutuhkan atau tidak. Tahap ini juga merupakan penilaian terhadap informasi yang telah diperoleh. Ellis, Cox, dan Hall dalam Sugiyantono (2016: 7.28) menyatakan bahwa berdasarkan penelitiannya, peneliti ilmu sosial tidak melakukan tahap ini, tidak seperti ilmuwan dalam bidang ilmu murni yang melakukan tahap ini untuk memastikan bahwa tidak ada kesalahan dalam perolehan informasi. Hasil penelitian terhadap pemustaka UNP dan Unand menunjukkan bahwa pengguna yang berasal dari bidang ilmu sosial juga melakukan tahap ini.

Kedelapan, tahap ending yang merupakan tahap akhir penelusuran informasi yang bersamaan dengan akhir dari suatu kegiatan. Pada tahap ini dapat diketahui apakah kualitas proses pembuatan tugas akademik memuaskan atau tidak.

Berdasarkan uraian di atas dapat diketahui bahwa model penelusuran informasi dari Ellis, Cox, dan Hall sejalan dengan kegiatan penelusuran informasi yang dilakukan oleh sebagian besar pemustaka UNP dan Unand. Tahap penelusuran informasi yang terkadang diabaikan oleh mahasiswa adalah merumuskan kebutuhan informasi, memprioritaskan penggunaan informasi dari sumber internet tanpa mengklarifikasi informasi dan sumber secara jelas. Setiawan (2017: 8) menyatakan perlunya strategi pencarian dan keterampilan teknologi untuk mendapatkan sumber informasi yang tepat yang tersedia di internet dan literasi informasi adalah dasar untuk melacak informasi dengan cepat dan akurat. Selain itu, terkadang pemustaka tidak mengekstrak informasi yang diperoleh dengan menggunakan kalimat dan pemahamannya sendiri, sehingga tidak diketahui tingkat pemahaman terhadap informasi yang didapat. 
Dalam pelaksanaan tridharma perguruan tinggi, pemutakhiran dan pengembangan informasi, serta keaslian tulisan ilmiah menjadi perhatian untuk peningkatan kualitas keilmuan. Model penelusuran informasi ini dapat menjadi acuan bagi mahasiswa maupun dosen dalam menghasilkan karya ilmiah yang berkualitas.

\section{Strategi Literasi Informasi}

Literasi informasi sekarang menjadi bagian penting dalam materi pendidikan. Berdasarkan model penelusuran informasi dari Ellis, Cox, dan Hall dalam Sugiyantono (2016: 7.26) dan mengadopsi beberapa standar literasi informasi oleh Association of College and Research of Library (ACRL) (2000), kemampuan literasi informasi dapat dirumuskan sebagai berikut. (1) Mengidentifikasi dan mengkomunikasikan kebutuhan informasi. (2) Mengidentifikasi berbagai jenis dan bentuk sumber informasi potensial. (3) Memilih dan menggunakan informasi dengan berbagai metode. (4) Mengutip, mencatat dan memproses informasi dan sumber-sumbernya. (5) Meringkas gagasan utama yang dikutip dari informasi yang dikumpulkan. (6) Menyimulasikan gagasan utama untuk membangun konsep baru. (7) Mengkomunikasikan hasil secara efektif kepada orang lain. (8) Mengetahui penggunaan sumber informasi dalam mengkomunikasikan informasi.

Sejalan dengan standar literasi informasi di atas, strategi penerapan literasi informasi di perguruan tinggi khususnya bagi mahasiswa dapat dirumuskan sebagai berikut. (1) Mengenalkan mahasiswa untuk mengetahui kebutuhan informasinya melalui perumusan pertanyaan untuk menjawab tugas akademik yang diberikan. (2) Memperkenalkan sumber informasi yang bisa dijadikan referensi dalam pencarian informasi baik dari segi jenis maupun bentuknya. Dalam hal jenis informasi adalah sumber informasi primer, sekunder, dan tersier. Dari segi bentuk, seperti: buku, majalah, sumber elektronik, dan lain-lain. Dalam hal ini diperkenalkan sumber informasi apa yang dimiliki oleh perguruan tinggi. (3) Memperkenalkan penggunaan sistem informasi perpustakaan, sekaligus sarana untuk mendapatkan informasi yang mudah diakses, seperti: katalog online perpustakaan, alat bibliografi, atau 
penggunaan layanan internet untuk mengakses sumber informasi online. (4) Menetapkan pengambilan informasi dengan menggunakan banyak sumber informasi dengan memasukkan informasi bibliografi lengkap dan memastikan sumber informasi dapat dilacak, dan menetapkan rekaman informasi yang dikutip dari sumbernya. (5) Membiasakan mahasiswa kembali informasi yang telah ditulis menggunakan kalimat mereka sendiri, serta untuk mengetahui tingkat pemahaman informasi yang telah diperoleh. (6) Mengarahkan mahasiswa untuk memikirkan atau mengemukakan gagasan lain yang sebanding dengan informasi yang telah diungkapkan. (7) Menyediakan sarana penyampaian informasi mengenai rumusan atau gagasan yang telah dihasilkan dalam bentuk komunikasi dua arah, baik dalam bentuk lisan maupun tulisan. (8) Menekankan manfaat informasi yang diperoleh untuk diri mereka dan lingkungan mereka, baik secara teoritis maupun praktis.

Strategi ini bisa digunakan untuk life-long learning dan pemecahan masalah dalam berbagai bentuk. Kemampuan literasi informasi yang selalu diasah dan digunakan, dapat menciptakan generasi muda yang mumpuni dan produktif. Selain itu, juga bisa mengurangi konsumsi informasi instan yang tidak jelas sumbernya. Pemustaka yang paham dengan literasi informasi, tahu kapan informasi dibutuhkan dan tahu bagaimana cara menggunakan informasi secara efektif.

\section{Efektivitas Penelusuran Informasi}

Aktivitas penelusuran informasi pemustaka dalam lingkungan perguruan tinggi perlu didikung oleh pustakawan dengan menerapkan berbagai strategi untuk memaksimalkan pendayagunaan sumber-sumber informasi di perpustakaan. Beberapa strategi yang dapat dilakukan pustakawan untuk mendukung efektivitas penelusuran informasi di perpustakaan perguruan tinggi adalah sebagai berikut.

Pertama, menyediakan sarana temu kembali informasi dalam bentuk bibliografi beranotasi untuk semua koleksi buku. Sarana ini selain dibuat dalam bentuk tercetak, juga diintegrasikan dalam katalog perpustakaan, seperti OPAC. Selanjutnya sarana ini disebarkan ke pemustaka. Pustakawan 
tidak berdiam diri saja menunggu pemustaka mengakses sarana ini, karena pemustaka pada umumnya tidak tahu bahwa perpustakaan memiliki beragam sarana penelusuran informasi yang bisa membantu proses penelusuran informasinya di perpustakaan secara efektif dan efisien.

Kedua, membuat indeks beranotasi untuk koleksi terbitan berkala seperti surat kabar, majalah, jurnal, dan prosiding. Untuk indeks beranotasi surat kabar, minimal dipilih beberapa topik yang menjadi unggulan perguruan tinggi. Indeks ini dibuat secara berkelanjutan dan disediakan juga bentuk klipingnya. Untuk indeks beranotasi jurnal, dibuat dengan rinci informasi untuk temu kembali seluruh jurnal yang dilanggan perpustakaan baik tercetak maupun digital. Informasi yang ditampilkan pada OPAC tidak hanya judul jurnal saja, tetapi lebih rinci pada informasi artikel di dalam jurnal. Selain itu, sarana penelusuran yang berkaitan dengan ini adalah kumpulan abstrak yang berisi informasi ringkas dari hasil-hasil penelitian seperti tugas akhir mahasiswa dan laporan penelitian.

Ketiga, memaksimalkan pemanfaatan sumber-sumber elektronik oleh pemustaka dengan memberikan bimbingan secara individual. Banmyak pemustaka tidak mengetahui cara menggunakan sumber-sumber ini. Padahal perpustakaan perguruan tinggi pada umumnya memiliki jenis informasi ini. Ketidaktahuan pemustaka tentang sumber informasi lain di perpustakaan dan kurangnya promosi dari pustakawan mengakibatkan sumber-sumber jenis ini sering tidak dimanfaatkan, hanya tersimpan rapi saja di perpustakaan. Contohnya sumber-sumber elektronik dalam bentuk artikel, audio visual, dan lain-lain.

Keempat, pustakawan mendayagunakan informasi yang tersedia dalam sumber-sumber online untuk menjawab kebutuhan informasi pemustaka. Hendaknya pustakawan masa sekarang tidak lagi mengatakan "tidak tahu" terhadap pertanyaan-pertanyaan pemustaka tentang suatu informasi yang dicarinya. Informasi yang terdapat dalam sumber-sumber online bisa dijadikan sebagai rujukan bagi pustakawan untuk memperlancar pekerjaan dalam pemenuhan informasi pemustaka. Selain itu, pustakawan juga dapat membimbing pemustaka dalam menemukan informasi yang 
relevan dengan kebutuhan pemustaka melalui sumber-sumber online. Untuk memenuhi hal tersebut, pustakawan juga diharapkan memiliki keterampilan dan keahlian dalam penelusuran informasi online.

\section{Kesimpulan}

Penelusuran informasi pada pemustaka perguruan tinggi banyak menggunakan sumber-sumber internet. Pustakawan di perguruan tinggi perlu membuat berbagai sarana temu balik informasi yang cukup untuk berbagai jenis sumber-sumber informasi perpustakaan. Penelusuran informasi sangat terkait dengan proses literasi informasi, dimana pemustaka sebagai pencari informasi dapat mencari, menemukan, dan memanfaatkan informasi secara efektif dan efisien. Untuk mendukung proses ini, pustakawan dapat membuat strategi-strategi yang dapat memudahkan pemustaka dalam melakukan penelusuran informasi di perpustakaan.

\section{Referensi}

Association of College and Research Libraries (ACRL). 2000. Information Literacy Competency Standards for Higher Education. http://www. ala.org/acrl/sites/ala.org.acrl/files/content/standards/standards.pdf, September 14, 2017.

Reitz, J. M. 2011. Online Dictionary for Library and Information Science.http:// www.abc-clio.com/ODLIS/searchODLIS.aspx, September 14, 2017.

Rifai, A. Penelusuran Literatur. Tangerang Selatan: Universitas Terbuka, 2014. Septiyantono, T. Literasi Informasi. Tangerang Selatan: Universitas Terbuka, 2016. Setiawan, V. Librarian Communication Strategy in the Implementation of Information Literacy (Case Study in University with Using and Exploiting E-resources. Jurnal Penelitian Komunikasi dan Opini Publik, Vol. 21, no. 1 (2017): 15-29.

Undang-Undang No. 43 Tahun 2007 Tentang Perpustakaan. http://www. pnri.go.id/law/undang-undang-nomor-43-tahun-2007-tentangperpustakaan/, diakses September 14, 2017. 